NOTE

\title{
Granulosa cell tumour in a harbour porpoise (Phocoena phocoena) from German waters
}

\author{
Henrike Seibel $^{1, *}$, Ursula Siebert ${ }^{1}$, Hanna Schöpper ${ }^{1}$, Peter Wohlsein ${ }^{2}$ \\ ${ }^{1}$ Institute of Terrestrial and Aquatic Wildlife Research (ITAW), University of Veterinary Medicine Hannover, Foundation, \\ Werftstrasse 6, 25761 Büsum, Germany \\ ${ }^{2}$ Department of Pathology, University of Veterinary Medicine Hannover, Foundation, Bünteweg 17, 30559 Hannover, \\ Germany
}

\begin{abstract}
Neoplastic diseases in harbour porpoises Phocoena phocoena have rarely been described, and there are no reported gonadal stromal tumours. A 12 yr old female harbour porpoise was stranded on the North Sea coast of Schleswig-Holstein, Germany. Necropsy findings included a severe granulomatous pneumonia, pregnancy and a left ovarian tumour. Respiratory insufficiency was the likely cause of death. There was a multinodular mass composed of cords with peripherally palisading cells within the left ovary. The histological and cytological appearance of the neoplasm was suggestive of a granulosa cell tumour; supportive immunohistochemical stains, including those for vimentin, cytokeration, carcinoembryonic antigen, c-kit, chromogranin and $\alpha$-smooth muscle action, were negative.
\end{abstract}

KEY WORDS: Harbour porpoise $\cdot$ Phocoena phocoena $\cdot$ Neoplasia $\cdot$ Ovary $\cdot$ Granulosa cell tumour Resale or republication not permitted without written consent of the publisher

\section{INTRODUCTION}

Types and distribution of tumours in marine mammals are assumed to be similar to those of domestic species. But the number of reported neoplasms is rare because many marine mammals die before reaching old age, when most neoplasms occur, or die at sea and do not become stranded on shore (Siebert et al. 2006). Overall, the reported incidence of neoplasms in whales, cetaceans and pinnipeds appears to be low (Newman \& Smith 2006). Analyses on carcass-detection rates in the Gulf of Mexico show that carcasses were recovered only from an average of $2.0 \%$ of the population (Williams et al. 2011). This low incidence results most likely from many unnoticed deaths in wild populations or lack of observed histological changes in tissue samples from necropsies due to advanced autolytic changes that occur during the marked time period between death and examination of the animal. The female genital tract represents one of the most commonly affected organ systems in cetaceans affected with neoplasms, which have been reported at an incidence of $21 \%$ (Geraci et al. 1987). Ovarian tumours found in marine mammals include adenocarcinoma, adenoma, dysgerminoma, mucinous cystadenoma, carcinoma and granulosa cell tumours (Rewell \& Willis 1949, Stolk 1950, Mawdesley-Thomas 1971, 1974, Landy 1980, Howard et al. 1983, Benirschke \& Marsh 1984, Martineau et al. 1988, De Guise et al. 1994, Van Bressem et al. 2000).

Granulosa cell tumours represent gonadal stromal tumours and are the most common ovarian neoplasms in large domestic animals (Foster 2007). They are composed primarily of cells that resemble the granulosa cells of the follicle. The tumour cells grow in a variety of patterns including micro- and macro- 
follicular, trabecular, insular and diffuse types (Kiyokawa et al. 2003). Besides granulosa cells, theca or luteinised cells and fibroblasts are found. Granulosa cell tumours have been described in a fin whale Balaenoptera physalus, a blue whale B. musculus, a short-finned pilot whale Globicephala macrorhynchus, beluga whales Delphinapterus leucas, a California sea lion Zalaphus californianus, a fur seal Callorhinis ursinis and a cape fur seal Arctocephalus pusillus (Rewell \& Willis 1949, Landy 1980, Howard et al. 1983, Benirschke \& Marsh 1984, Martineau et al. 1988, De Guise et al. 1994).

Systematic pathological investigations have been performed on harbour porpoises Phocoena phocoena from several different regions (Baker \& Martin 1992, Siebert et al. 2001, 2006, Jauniaux et al. 2002, Jepson et al. 2005), but only a few neoplastic diseases are reported, including a cutaneous squamous papilloma (Geraci et al. 1987), one gastric adenocarcinoma with multiple metastases (Breuer et al. 1989), one adenocarcinoma involving the posterior abdominal tissues with large numbers of secondary tumours on the serosal surface (Baker \& Martin 1992), an adrenal papilloma (Newman \& Smith 2006) and a gastric squamous cell carcinoma (Siebert et al. 2010). In this paper the morphological findings of an ovarian granulosa cell tumour in a harbour porpoise are described.

A female 12 yr old harbour porpoise, measuring $160 \mathrm{~cm}$ and weighing $78.8 \mathrm{~kg}$, was stranded at the western shore of the North Sea coast on the island of Sylt, Germany. The age was determined by counting the annual growth layers of teeth from the middle of the lower jaw (Agedynamics, Denmark; Lockyer 1995). Until the post-mortem examination could be performed the carcass was stored at $-20^{\circ} \mathrm{C}$. The necropsy was performed according to standardised European necropsy protocols for cetaceans (Siebert et al. 2001). Tissue samples were collected from different organs and tissues (skin, muscles, brain, tongue, heart, lung, diaphragm, stomach, kidneys, liver, spleen, pancreas, intestine, adrenal glands, ovaries, genital mucosa and different regional lymph nodes) fixed in 10\% neutral buffered formalin and embedded in paraffin wax. The $5 \mu \mathrm{m}$ thick tissue sections were stained with haematoxylin and eosin (H\&E) and selected slides were stained with elastica van Gieson and Gomori's reticulin stains and for periodic acid Schiff (PAS) reaction. For immunohistochemistry, murine monoclonal and, in harbour porpoise tissue, cross-reacting antibodies against vimentin (clone V9), cytokeratin (CK7 clone OVTL12/30, AE1/AE3 clone AE1/AE3 against CK1 to
CK8, CK10, CK13 to CK16, CK19,), carcinoembryonic antigen (CEA) c-kit, chromogranin and $\alpha$-smooth muscle actin (clone 1A4, all from DAKO Cytomation) were applied using the avidin-biotin-peroxidase complex (ABC) method (Vector Laboratories) (Döpke et al. 2007). Positive controls consisted of unmodified ovarian tissue from another adult harbour porpoise. Liver, spleen, kidneys, lung, pleural and mesenteric lymph nodes and tumour tissue were cultured for bacteria.

On postmortem examination the animal was in moderate decomposition after thawing. The porpoise was in a good nutritional status and pregnant with a fully developed male foetus, which measured $75 \mathrm{~cm}$ (tip of rostrum to fluke notch) and weighed $5 \mathrm{~kg}$, located in the left uterine horn. The left ovary was almost completely replaced by a large, $18.0 \times 15.0 \times$ $16.0 \mathrm{~cm}$, multinodular mass consisting of three $7.0 \mathrm{~cm}$ nodules, two $1.0 \times 2.0 \times 2.0 \mathrm{~cm}$ nodules, and a $3.0 \times$ $3.0 \times 3.0 \mathrm{~cm}$ cyst containing serous fluid (Fig. 1). Nodules were separated by connective tissue. On the cut surface the tissue was irregularly coloured yellow, red or black and had a smooth and shiny surface, few areas of haemorrhage and a well-demarcated necrotic region $3.5 \mathrm{~cm}$ in diameter. The 2 smaller foci were composed of a light red pasty mass. In addition a cyst $(3.0 \times 3.0 \times 3.0 \mathrm{~cm})$ containing red clear serous fluid was bulging from the tumour's surface (Fig. 1). The right ovary was $4.0 \times 3.0 \times 1.5 \mathrm{~cm}$ in size with a

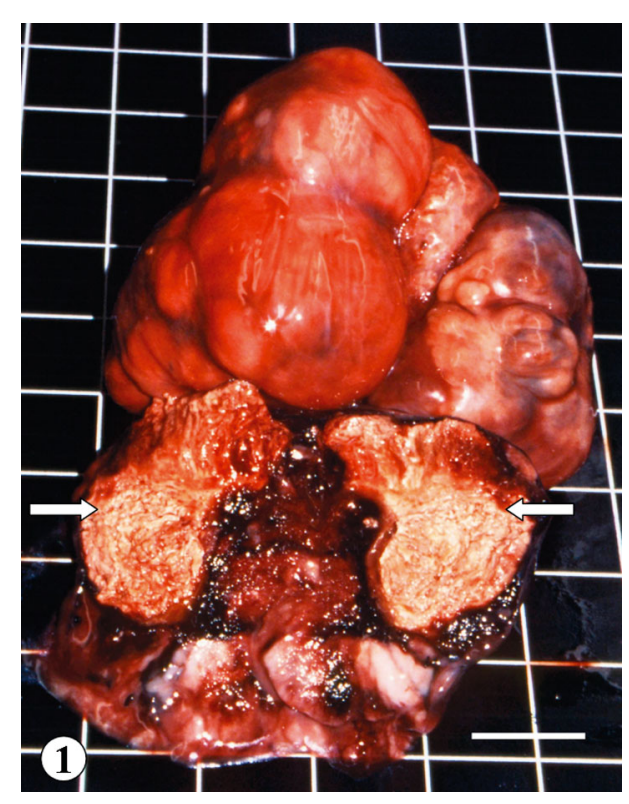

Fig. 1. Phocoena phocoena. Granulosa cell tumour of a harbour porpoise showing a coarse nodular surface and the cut surface (arrows) of a nodule. Scale bar $=3 \mathrm{~cm}$ 
corpus luteum of $1.5 \mathrm{~cm}$ in diameter. In the lungs, there were multifocal granulomas with necrotic centres and severe diffuse pulmonary oedemas, and the lungs indicated moderate emphysema. In the bronchial tree and the pulmonary blood vessels a mild to moderate parasitic infestation of nematodes (Pseudalius inflexus, Torynurus convolutus and Halocercus invaginatus) was found. In the liver, there were a few trematodes observed within thickened bile ducts (chronic proliferative cholangitis).

Histologically, there was a granulosa cell tumour in the left ovary. The tumour was arranged in cords (Fig. 2) separated by thin, Gomori-positive, reticulin fibres (Fig. 3). The tumour cells had abundant eosinophilic cytoplasm and a round to oval, often eccentric, nucleus with distinct nucleoli. Mitotic activity was evident in fewer than 1 per 10 cells as viewed under high magnification. Additional findings included collagenolysis with dystrophic mineralisation. All available immunohistochemical stains of the ovary were negative, while positive controls were positive.

There were a severe diffuse alveolar oedema and moderate diffuse alveolar emphysema as well as a severe multifocal chronic granulomatous pneumonia as shown by central necrosis with pulmonary endoparasitosis in airways and vessels.

Additional histological findings included moderate hyalinosis of the Bowman's capsules of the kidney, a severe focal calcification of splenic trabeculae with severe haemosiderin and haematoidin deposits, a moderate chronic proliferative cholangitis and a mild focal mural lymphohistiocytic colitis. These lesions were incidental findings and not related to the animal becoming stranded.

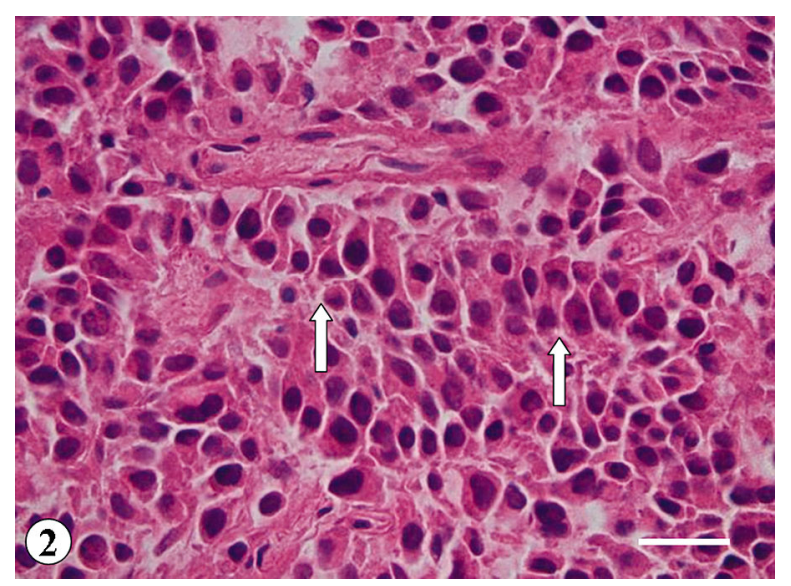

Fig. 2. Phocoena phocoena. Tumour cells of the granulosa cell tumour are arranged in cords (arrows). H\&E stain. Scale bar $=80 \mu \mathrm{m}$

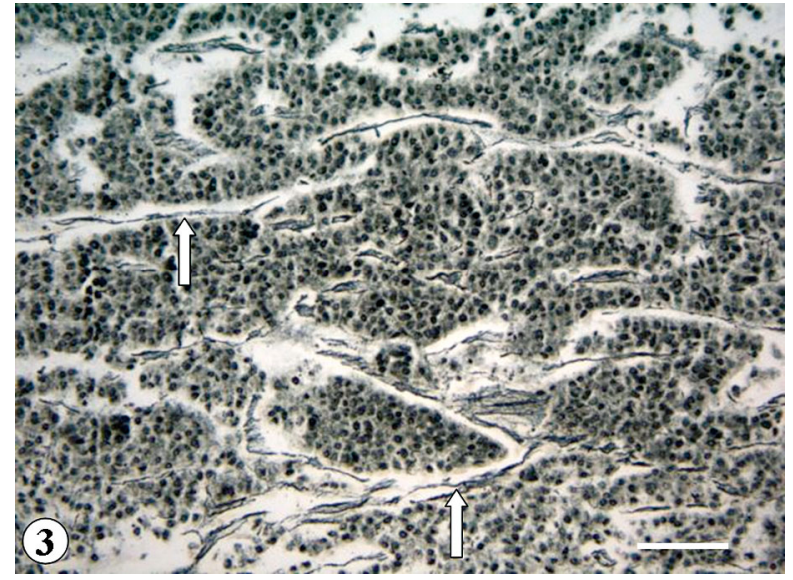

Fig. 3. Phocoena phocoena. Cords of tumourous granulosa cells are surrounded by a network of reticulin fibres

(arrows). Gomori's reticulin stain. Scale bar $=120 \mu \mathrm{m}$

The microscopical and histological examination of the foetus revealed no morphological lesions. Immunohistochemical examination indicated there was no specific labelling of the tumour cells with any of the antibodies that were applied.

Bacteriological examination of lung, liver, spleen, kidney, intestine, tumour tissue and mesenteric and pleural lymph nodes resulted in isolation of nonspecific bacteria. Mild to moderate amounts of Streptococcus sp., Escherichia coli, coliform bacteria, Acinteobacter sp., Pseudomonas sp., Citrobacter diversus, Serratia sp. and Clostridium perfringens type A were present in several organs. There was no histological evidence of septicaemia and no associated lesions were detectable, so it is assumed that these mixed bacteria were post mortem.

The death of this 12 yr old female harbour porpoise was attributed to severe verminous pneumonia leading to respiratory insufficiency. Pneumonia is the cause of death in $46 \%$ of stranded subadult and adult harbour porpoises in German waters and two-thirds of these deaths are associated with nematodes (Siebert et al. 2001).

The porpoise had a granulosa cell tumour in the left ovary. The histological pattern of tumour cell arrangement was similar to that found in domestic animals (Nielsen et al. 1976, MacLachlan 1987, Kiyokawa et al. 2003). Other ovarian tumours were considered including thecomas; however, thecomas contain abundant intercellular reticulin (Kennedy et al. 1998, Tavassoli et al. 2003), which was not observed in this case.

Immunohistochemistry using various monoclonal antibodies failed to label the tumour cells. Human 
granulosa cell tumours express, among others, vimentin, cytokeratin, S100 protein and $\alpha$-smooth muscle actin (Tavassoli et al. 2003). Immunolabelling for vimentin, cytokeratin, and inhibin- $\alpha$ has been described in dogs (Riccardi et al. 2007). The negative immunohistochemical results in this particular case may be caused by the loss of epitopes due to decomposition, freezing and thawing of the carcass or duration of fixation in formalin. A lack of phylogenic conservation of epitopes may also be a reason for the lack of staining.

In humans 2 distinct types of granulosa cell tumours exist and are known as adult and juvenile. They typically occur most commonly in older females, but the juvenile ones account for about the $5 \%$ of all granulosa cell tumours in humans (Hasiakos et al. 2006). Only $10 \%$ of these tumours present during pregnancy (Fernández-Cid et al. 2011). Granulosa cell tumours produce and store a variety of steroid hormones (Tavassoli et al. 2003, Schlafer \& Miller 2007). Functionally, neoplasms and most granulosa cell tumours produce oestrogenic hormones but, on rare occasions, androgenic activity may occur. In the described case, there was most likely no hormonal synthesis, because the porpoise was reproductively active and pregnant with a fully developed foetus. Unfortunately there have been no crossreacting antibodies for an immunohistochemical investigation of the presence of alpha-inhibin, estrogen and progesterone.

The occurrence of the tumour in the left ovary led to hormonal support of pregnancy in the right ovary, which may be an atypical occurrence in cetaceans. In cetaceans normally foetuses are carried in the left uterine horn (Schulze 1996), and the left ovary helps to maintain the gravid corpus luteum (Halldórsson \& Víkingsson 2003). In this case, the tumour was located in the left ovary, while a corpus luteum was found in the right ovary, presumably supporting pregnancy. In normal pregnancies of domestic animals, there is atrophy of the contra-lateral ovary (Schlafer \& Miller 2007).

Although the incidence of neoplasia is increasing in marine mammals (Newman \& Smith 2006) and tumour rates are described to be relatively high in certain regions (Martineau et al. 2002), possibly due to environmental contamination or exposure to viral pathogens (Gulland et al. 1996, Newman \& Smith 2006), the prevalence of tumours in harbour porpoises is low. However, continued efforts should be made to perform monitoring programs on marine mammals to increase our knowledge about their health status, because they may play an important role as sentinel animals.
Acknowledgements. The harbour porpoise was investigated as part of a health monitoring on small cetaceans funded by the Schleswig-Holstein Ministry of Agriculture, Environment and Rural Areas. Special thanks to B. Buck and P. Grüning for histological and immunohistological preparations, Dr. C. Lockyer for age-determination, and Dr. R. Weiss for bacteriological investigation.

\section{LITERATURE CITED}

Baker JR, Martin AR (1992) Causes of mortality and parasites and intestinal lesions in harbour porpoises (Phocoena phocoena) from British waters. Vet Rec 130: 554-558

Benirschke K, Marsh H (1984) Anatomic and pathological observations of female reproductive organs in the shortfinned pilot whale, Globicephalus macrorhynchus. Rep Int Whaling Comm (Spec Issue 6):451-455

Breuer EM, Krebs BH, Hofmeister RJ (1989) Metastasizing adenocarcinoma of the stomach in a harbour porpoise, Phocoena phocoena. Dis Aquat Org 7:159-163

> De Guise S, Lagacé A, Béland P (1994) Tumors in St. Lawrence beluga whales (Delphinapterus leucas). Vet Pathol 31:444-449

Döpke C, Fehr M, Thiele A, Pohlenz J, Wohlsein P (2007) Morphological and immunohistochemical characterization of spontaneous mammary tumours in European hedgehogs (Erinaceus europaeus). J Comp Pathol 137: $22-29$

Fernández-Cid M, Pascual MA, Graupera B, Hereter L, Cusidó MT, Tresserra F, Rotili A (2011) Adult granulosa cell tumour of the ovary associated with pregnancy. J Obstet Gynaecol 31:272-274

Foster RA (2007) Female reproductive system. In: McGavin MD, Zachary JZ (eds) Pathologic basis of veterinary disease. Mosby Elsevier, St. Louis, MO, p 1263-1315

> Geraci JR, Palmer NC, St Aubin DJ (1987) Tumors in cetaceans: analysis and new findings. Can J Fish Aquat Sci 44:1289-1300

Gulland FMD, Trupkiewicz JG, Spraker TR, Lowenstine LJ (1996) Metastatic carcinoma of probable transitional cell origin in 66 free-living California sea lions (Zalophus californicus), 1979 to 1994. J Wild Life Dis 32:250-258

Halldórsson SD, Víkingsson GA (2003) Analysis of seasonal changes in reproductive organs from Icelandic harbour porpoises (Phocoena phocoena). In: Haug $T$, Desportes G, Víkingsson G, Witting L (eds) Harbour porpoises in the North Atlantic. The North Atlantic Marine Mammal Commission, Tromsø, p 121-141

Hasiakos D, Papakonstantinou K, Goula K, Karvouni E, Fotiou S (2006) Juvenile granulosa cell tumor associated with pregnancy: report of a case and review of the literature. Gynecol Oncol 100:426-429

Howard EG, Britt FO, Simpson JG (1983) Neoplasms in marine mammals. In: Howard EG (ed) Pathobiology of marine mammal diseases. CRC Press, Boca Raton, FL, p 95-162

Jauniaux T, Petitjean D, Brenez C, Borrens $M$ and others (2002) Post-mortem findings and causes of death of harbour porpoises (Phocoena phocoena) stranded from 1990 to 2000 along the coastlines of Belgium and northern France. J Comp Pathol 126:243-253

Jepson PD, Bennett PM, Deaville R, Allchin CR, Baker JR, Law RJ (2005) Relationships between polychlorinated 
biphenyls and health status in harbor porpoises (Phocoena phocoena) stranded in the United Kingdom. Environ Toxicol Chem 24:238-248

Kennedy PC, Cullen JM, Edwards JF, Goldschmidt MH, Larsen S, Munson L, Nielson S (1998) Histological classification of tumors of the genital system of domestic animals. Armed Forces Institute of Pathology, Washington, DC

Kiyokawa T, Schwartz P, Kubik-Huch RA, Roth LM (2003) Sex cord stromal tumours. In: Tavassoli FA, Devilee P (eds) Pathology and genetics tumours of the breast and female genital organs. WHO classification of tumours. International Agency of Cancer Press, Lyon, p 146-162

Landy RB (1980) A review of neoplasia in marine mammals (Pinnipedia and Cetacea). In: Montali RG, Migaki G (eds) The comparative pathology of zoo animals. Smithsonian Institution Press, Washington, DC, p 579-584

Lockyer C (1995) A review of factors involved in zonation in odontocete teeth, and an investigation of the likely impact of environmental factors and major life events on harbour porpoise tooth structure. In: Bjørge A, Donovan GP (eds) The biology of the phocoenids: a collection of papers. International Whaling Commission, Cambridge, p 511-529

MacLachlan NJ (1987) Ovarian disorders in domestic animals. Environ Health Perspect 73:27-33

Martineau D, Lagacé A, Béland P, Higgins R, Armstrong D, Shugart LR (1988) Pathology of stranded beluga whales (Delphinapterus leucas) from the St. Lawrence Estuary, Quebec, Canada. J Comp Pathol 98:287-311

Martineau D, Lemberger K, Dallaire A, Labelle P, Lipscomb TP, Michel P, Mikaelian I (2002) Cancer in wildlife, a case study: belugas from St. Lawrence Estuary, Québec, Canada. Environ Health Perspect 110:285-292

Mawdesley-Thomas LE (1971) An ovarian tumor in a southern elephant seal. Vet Pathol 8:9-15

Mawdesley-Thomas LE (1974) Some aspects of neoplasia in marine mammals. In: Russel FS, Yonge B (eds) Advances in marine biology, Vol 12. Academic Press, New York, NY, p 151-231

Newman SJ, Smith SA (2006) Marine mammal neoplasia: a review. Vet Pathol 43:865-880

Editorial responsibility: Michael Moore,

Woods Hole, Massachusetts, USA
Nielsen SW, Misdorp W, McEntree K (1976) Tumours of the ovary. Bull World Health Organ 53:203-215

Rewell RE, Willis RA (1949) Some tumours found in whales. J Pathol Bacteriol 61:454-456

Riccardi E, Grieco V, Verganti S, Finazzi M (2007) Immunhistochemical diagnosis of canine ovarian epithelial and granulosa cell tumors. J Vet Diagn Invest 19:431-435

Schlafer DH, Miller RB (2007) Neoplastic diseases of the ovary. In: Grant Maxie M (ed) Jubb, Kennedy, and Palmer's pathology of domestic animals, 5th edn. Elsevier Saunders, Philadelphia, PA, p 450-456

Schulze G (1996) Die Schweinswale, Familie Phocoenidae. In: Schulze G (ed) Die neue Brehm-Bücherei, Vol 583. Spektrum Akademischer Verlag, Heidelberg, p 88-97

> Siebert U, Wünschmann A, Weiss R, Frank H, Benke H, Frese K (2001) Post-mortem findings in harbour porpoise (Phocoena phocoena) from the German North and Baltic seas. J Comp Pathol 124:102-114

Siebert U, Tolley K, Vikingsson GA, Ólafsdottir D, Lehnert K, Weiss R, Baumgärtner W (2006) Pathological findings in harbour porpoises (Phocoena phocoena) from Norwegian and Icelandic waters. J Comp Pathol 134:134-142

> Siebert U, Hasselmeier I, Wohlsein P (2010) Immunohistochemical characterization of a squamous cell carcinoma in a harbour porpoise (Phocoena phocoena) from German waters. J Comp Pathol 143:179-184

Stolk A (1950) Tumors in whales. Am Nat 1:28-33

Tavassoli FA, Mooney E, Gersell DJ, McCluggage WG and others (2003) Sex cord-stromal tumours. In: Tavassoli FA, Devilee P (eds) WHO classification of tumours. Pathology and genetics of tumours of the breast and female genital organs. International Agency of Cancer Press, Lyon, p 146-161

Van Bressem MF, Van Waerenbeek K, Siebert U, Wünschmann A, Chavez-Lisambart L, Reyes JC (2000) Genital diseases in the Peruvian dusky dolphin (Lagenorhynchus obscurus). J Comp Pathol 122:266-277

> Williams R, Gero S, Bejder L, Calambokidis J and others (2011) Underestimating the damage: interpreting cetacean carcass recoveries in the context of the Deepwater Horizon/BP incident. Conserv Lett 4:228-233

Submitted: June 1, 2011; Accepted: January 30, 2012

Proofs received from author(s): April 23, 2012 